\title{
Redox Report
}

\section{4-Hour variation in gene expression of redox pathway enzymes in rat hypothalamus: effect of melatonin treatment}

\author{
Vanesa Jiménez-Ortega, Pilar Cano, Daniel P. Cardinali \& Ana I. Esquifino
}

To cite this article: Vanesa Jiménez-Ortega, Pilar Cano, Daniel P. Cardinali \& Ana I. Esquifino (2009) 24-Hour variation in gene expression of redox pathway enzymes in rat hypothalamus: effect of melatonin treatment, Redox Report, 14:3, 132-138, DOI: 10.1179/135100009X392548

To link to this article: https://doi.org/10.1179/135100009X392548

Published online: 19 Jul 2013.

Submit your article to this journal $\square$

Џ Article views: 61

Q View related articles $\sqsubset$

Citing articles: 23 View citing articles 5 


\title{
24-Hour variation in gene expression of redox pathway enzymes in rat hypothalamus: effect of melatonin treatment
}

\author{
Vanesa Jiménez-Ortega ${ }^{1}$, Pilar Cano ${ }^{1}$, Daniel P. Cardinali², Ana I. Esquifino ${ }^{1}$ \\ ${ }^{1}$ Department of Biochemistry and Molecular Biology III, School of Medicine, Universidad Complutense, \\ Madrid, Spain \\ ${ }^{2}$ Department of Teaching \& Research, Pontificia Universidad Católica Argentina, Buenos Aires, \\ Argentina
}

The 24-h changes in medial basal hypothalamic $(\mathrm{MBH})$ gene expression of redox pathway enzymes nitric oxide synthase (NOS)-1 and NOS-2, heme oxygenase (HO)-1 and HO-2, Cu/Znand $\mathrm{Mn}$-superoxide dismutases (SOD) and catalase were examined in adult male Wistar rats kept under an alternating regimen of light/dark. Half of the animals received melatonin ( $60 \mu \mathrm{g} /$ day $)$ in the drinking water. After 1 month, rats were killed at six different time intervals, throughout a 24-h cycle. MBH mRNA levels were measured by real-time PCR analysis. In controls, gene expression of NOS-2 and HO-2 peaked at the early light phase while that of $\mathrm{HO}-1$ showed a maximum at the middle of the dark phase. None of MBH mRNAs encoding NOS-1, Cu/Zn-SOD, Mn-SOD and catalase exhibited significant 24-h variations in control rats. Melatonin administration decreased significantly mRNAs for NOS-1, NOS-2, HO-1 and HO-2 as well as changed their 24-h profile. Melatonin augmented gene expression of the antioxidant enzymes Cu/Zn-SOD, Mn-SOD or catalase at certain time intervals only. The results are compatible with the view that the principal indirect (i.e. gene expression of redox pathway enzymes) effect of melatonin on redox pathway in the hypothalamus is mainly exerted via down-regulation of pro-oxidant enzyme mRNAs.

Keywords: melatonin, circadian rhythms, gene expression, medial basal hypothalamus, nitric oxide synthase, heme oxygenase,

superoxide dismutase, catalase

\section{Introduction}

Because reactive oxygen species (ROS) generation in the brain is a continuous and physiological phenomenon, nerve cells possess efficient antioxidant systems that protect them from oxidative damage (for a review, see Mancuso et al. $\left.{ }^{1}\right)$. These defense systems are thought to prevent free radicals from causing

Correspondence to: D.P. Cardinali MD PhD, Department of Teaching \& Research, Faculty of Medical Sciences, Pontificia Universidad Católica Argentina, Av. Alicia Moreau de Justo 1500,40 piso, 1107 Buenos Aires, Argentina. Tel/Fax: +54 11 59509611; E-mail: danielcardinali@uca.edu.ar

Received 4 September 2008; revised manuscript accepted 23 March 2009 irreparable damage by reacting with lipids, proteins and nucleic acids and are controlled in vivo by a wide spectrum of enzymatic and non-enzymatic systems.

Data accumulated in the last decade strongly indicate that melatonin plays an important role in this defense. ${ }^{2}$ Melatonin is a ubiquitous biological signaling molecule that has been identified in all major taxa of organisms, different plants, invertebrates, and vertebrates. Melatonin has diverse physiological functions, signaling not only the time of the day, or the season of the year, but also having immunomodulatory and cytoprotective roles. ${ }^{3}$

The regulation of enzymes involved in the redox pathway is one of the ways by which melatonin exerts 
its antioxidant, cytoprotective effects in the brain. Such a regulation involves both the down-regulation of prooxidant enzymes like nitric oxide (NO) synthase (NOS)4 or 5- and 12-lipoxygenases ${ }^{5}$ as well as the up-regulation of antioxidant enzymes like $\mathrm{Cu} / \mathrm{Zn}$ - and $\mathrm{Mn}$-superoxide dismutases (SOD), ${ }^{6}$ catalase, ${ }^{7}$ glutathione peroxidase, ${ }^{8}$ glutathione reductase ${ }^{9}$ or $\gamma$-glutamylcysteine synthase. ${ }^{10}$ This action is complementary to the non-enzymatic, radical scavenger effect that melatonin and some of its metabolites (notably $N^{1}$-acetyl- $N^{2}$-formyl-5-methoxykynuramine and $N^{1}$-acetyl-5-methoxykynuramine) have to scavenge ROS, reactive nitrogen species (RNS) and organic radicals. ${ }^{2}$

In mammals, the circadian system is composed of many individual, tissue-specific, cellular clocks whose phases are synchronized by a master circadian pacemaker residing in the suprachiasmatic nuclei of the hypothalamus. The redox state has been found to be important for the molecular mechanism of the circadian clock. ${ }^{11}$ Circadian variations of brain redox pathway enzymes have been described, including NOS, ${ }^{12}$ heme oxygenase (HO) $,{ }^{13} \mathrm{SOD},{ }^{14}$ and catalase. ${ }^{15}$ In many cases, rhythms in enzyme activity and gene expression coincide but in others they are out of phase (e.g. NOS). ${ }^{12}$ The present study was carried out to assess whether gene expression of the redox enzymes NOS-1, NOS-2, HO-1, HO-2, Cu/Zn-SOD, Mn-SOD and catalase exhibit 24-h periodicity in medial basal hypothalamus $(\mathrm{MBH})$ of rats. Since we previously reported a time-dependent effect of melatonin on NOS-1, NOS-2 and HO-1 gene expression in the hypothalamic-pituitary unit of rats, ${ }^{16}$ we wished to assess whether 24-h periodicity of MBH mRNAs encoding these redox enzymes was affected by the administration of melatonin in the drinking water.

\section{Materials and methods}

\section{Animals and experimental design}

Adult male Wistar rats (180-200 g body weight, 60 days of age at the beginning of the experiment) were supplied by the School of Medicine, University Complutense, Madrid, Spain). The rats were kept under standard conditions of controlled light (fluorescent cool white bulbs; 100 lux intensity at the level of cages; 12:12 h light/dark schedule; lights on at $0800 \mathrm{~h}$ ) and temperature $\left(22 \pm 2^{\circ} \mathrm{C}\right)$. Food and water were supplied ad libitum.

Half of the animals received melatonin $(3 \mu \mathrm{g} / \mathrm{ml})$ in drinking water. Administration of melatonin p.o. rather than systemically was selected because it resembled the way humans take melatonin. The stock solution of melatonin was prepared in 50\% ethanol; final ethanol concentration in drinking water was $0.015 \%$. Vehicletreated controls received $0.015 \%$ ethanol in drinking water. Drinking water bottles were changed every other day. Since rats drank about $20 \mathrm{ml} / \mathrm{day}$ with $90-95 \%$ of this total daily water taken up during the dark period, the melatonin dosage used provided approximately $60 \mu \mathrm{g}$ melatonin/day. This dose was 10 times higher than that needed to attain physiological circulating melatonin levels in pinealectomized rats. ${ }^{17}$ Nocturnal water consumption did not differ among the experimental groups.

After 1 month of treatment, groups of 6-8 rats were killed by decapitation at six different time intervals $(0900$, 1300, 1700, 2100, 0100 and $0500 \mathrm{~h}$ ) throughout a 24-h cycle. At night intervals, animals were killed under red dim light. The brains were rapidly removed and the medial basal hypothalamus (MBH) was dissected out following the landmarks of Szentagothai et al..$^{18}$ Tissues were kept frozen at $-70^{\circ} \mathrm{C}$ until further assayed. The care and use as well as all procedures involving animals were approved by the Institutional Animal Care Committee, Faculty of Medicine, Complutense University, Madrid. The study was in accordance with the guidelines of the Institutional Care and Use Committee of the National Institute on Drug Abuse, National Institutes of Health and the Guide for the Care and Use of Laboratory Animals. ${ }^{19}$

\section{Real-time quantitative polymerase chain reaction $(q P C R)$}

Total RNA extraction was performed using the RNeasy protect mini kit and was analyzed using QuantiTec SYBR green kit (Qiagen, Hielden, Germany). The iScript $^{\mathrm{TM}}$ cDNA Synthesis Kit (Bio-Rad Laboratories SA; Madrid, Spain) was used to synthesize cDNA from 1 $\mu \mathrm{g}$ of total RNA, according to the manufacturer's protocol. The house keeping gene $\beta$-actin was used as a constitutive control for normalization. Reactions were carried out in the presence of $200 \mathrm{nM}$ of specific primers. Primers were designed using Primer3 software (The Whitehead Institute, <http://frodo.wi.mit.edu/cgi-bin/ primer3/ primer3_www.cgi>) and are shown in Table 1.

PCR reactions were carried out in an AbiPrism 7300 (Applied Biosystems, Foster City, CA, USA). The real-time qPCR reaction program included a $94^{\circ} \mathrm{C}$ enzyme activation step for 2 min followed by 40 cycles of $95^{\circ} \mathrm{C}$ denaturation for $15 \mathrm{~s}, 60^{\circ} \mathrm{C}$ annealing for $30 \mathrm{~s}$ and $72^{\circ} \mathrm{C}$ extension for $30 \mathrm{~s}$. Detection of fluorescent product was carried out at the end of the $72^{\circ} \mathrm{C}$ extension period.

Serial dilutions of cDNA from control hypothalamus were used to perform calibration curves in order to determine amplification efficiencies. For the primers used there were no differences between 
Table 1 Sequence of the primers used for real-time PCR

\begin{tabular}{|c|c|c|c|}
\hline \multirow{2}{*}{$\begin{array}{l}\text { Gene } \\
\beta \text {-Actin }\end{array}$} & \multicolumn{2}{|c|}{ Primers } & \multirow{2}{*}{$\begin{array}{c}\text { Product } \\
\text { size (bp) }\end{array}$} \\
\hline & $\begin{array}{l}\text { Forward } \\
\text { Backward }\end{array}$ & $\begin{array}{l}\text { ctctcttccagccttccttc } \\
\text { ggtctttacggatgtcaacg }\end{array}$ & \\
\hline NOS-1 & $\begin{array}{l}\text { Forward } \\
\text { Backward }\end{array}$ & $\begin{array}{l}\text { atcggcgtccgtgactactg } \\
\text { tcctcatgtccaaatccatcttcttg }\end{array}$ & 92 \\
\hline NOS-2 & $\begin{array}{l}\text { Forward } \\
\text { Backward }\end{array}$ & $\begin{array}{l}\text { tggcctccctctggaaaga } \\
\text { ggtggtccatgatggtcacat }\end{array}$ & 93 \\
\hline $\mathrm{HO}-1$ & $\begin{array}{l}\text { Forward } \\
\text { Backward }\end{array}$ & $\begin{array}{l}\text { tgctcgcatgaacactctg } \\
\text { tcctctgtcagcagtgcc }\end{array}$ & 123 \\
\hline $\mathrm{HO}-2$ & $\begin{array}{l}\text { Forward } \\
\text { Backward }\end{array}$ & $\begin{array}{l}\text { agcaaagttggccttaccaa } \\
\text { gtttgtgctgccctcacttc }\end{array}$ & 84 \\
\hline $\mathrm{Cu} / \mathrm{Zn}-\mathrm{SOD}$ & $\begin{array}{l}\text { Forward } \\
\text { Backward }\end{array}$ & $\begin{array}{l}\text { ggtggtccacgagaaacaag } \\
\text { caatcacaccacaagccaag }\end{array}$ & 98 \\
\hline Mn-SOD & $\begin{array}{l}\text { Forward } \\
\text { Backward }\end{array}$ & $\begin{array}{l}\text { aaggagcaaggtcgcttaca } \\
\text { acacatcaatccccagcagt }\end{array}$ & 94 \\
\hline Catalase & $\begin{array}{l}\text { Forward } \\
\text { Backward }\end{array}$ & $\begin{array}{l}\text { gaatggctatggctcacaca } \\
\text { caagttttgatgccctggt }\end{array}$ & 100 \\
\hline
\end{tabular}

transcription efficiencies, the amount of initial cDNA in each sample being calculated by the $2^{-\Delta \Delta \mathrm{Ct}}$ method. ${ }^{20}$ All samples were analyzed in triplicate and in three different measures. Fractional cycle at which the amount of amplified target becomes significant $(\mathrm{Ct})$ was automatically calculated by the PCR device.

To estimate whether melatonin treatment or time of day modified the expression of $\beta$-actin, PCR with serial dilutions of this housekeeping gene was performed. Ct did not vary significantly as a function of treatment or of time of day, indicating the validity to employ $\beta$-actin as a housekeeping gene.

\section{Statistical analysis}

Statistical analysis of results was performed by a factorial analysis of variance (ANOVA). Generally, the ANOVA included assessment of treatment effect (i.e. the occurrence of differences in mean values between melatonin- and vehicle-fed rats), of time-ofday effects (the occurrence of daily changes) and of the interaction between treatment and time, from which inference about differences in timing and amplitude between the experimental groups could be obtained. Post-hoc Bonferroni's multiple comparisons tests in a one-way ANOVA were employed to show which time points were significantly different within each experimental group to define the existence of peaks. Student's $t$-tests were employed to define differences between melatonin- and vehicle-fed rats at specific time points. $P$-values lower than 0.05 were considered evidence for statistical significance.

\section{Results}

Figure 1 depicts the relative expression of MBH NOS1 and NOS-2 genes. In vehicle-treated controls, NOS-1 mRNA expression did not exhibit significant 24-h variations while that of NOS-2 peaked at the early light phase of daily photoperiod (0900 h). Melatonin treatment inhibited by $22 \%$ and $46 \%$ mRNA expression of NOS-1 and NOS-2, respectively, as shown by main factor analysis in the factorial ANOVA ( $\mathrm{F}=8.04$ and 68.3; $P<0.0001)$. Significant interactions 'treatment $\mathrm{x}$ time' were found for the two mRNA examined, a maximum in mRNA expression of NOS-1 and NOS-2 being found at $0900 \mathrm{~h}$ in melatonin-administered rats $(\mathrm{F}=2.74, P<0.03$; and $\mathrm{F}=3.78, P<0.001$, respectively; Fig. 1).
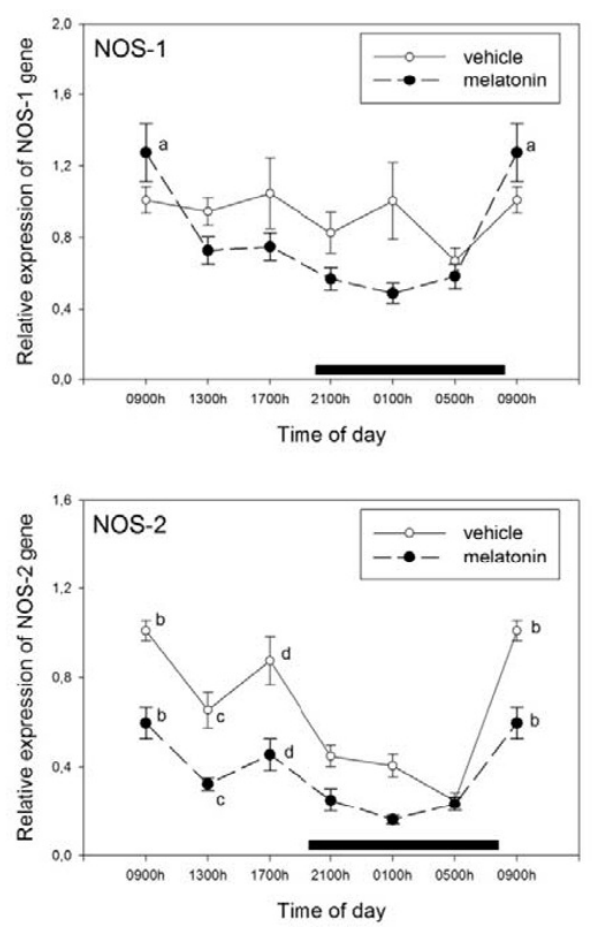

Figure 1 Effect of melatonin administration on 24-h changes in expression of mRNA for NOS-1 and NOS-2 in medial basal hypothalamus (MBH) of rats. Groups of 6-8 rats were killed by decapitation at six different time intervals throughout a 24-h cycle. MBH mRNA levels encoding the NOS-1 and NOS-2 enzymes were measured as described in the text. Shown are the mean values \pm SEM of mRNA determination as measured by triplicate real-time PCR analyses of RNA samples. Letters denote significant differences in a one-way ANOVA followed by a Bonferroni's multiple comparison test, as follows: a $P<0.01$ vs all other mean values; ${ }^{\mathrm{b}} P<0.05$ vs $1300 \mathrm{~h}, P<0.01$ vs 2100,0100 and 0500 h; ${ }^{\mathrm{C}} P<0.01$ vs 0100 and $0500 \mathrm{~h}, P<0.05$ vs $0900 \mathrm{~h}$; d $P<0.01$ vs 0100 and $0500 h$. For further statistical analysis, see text 

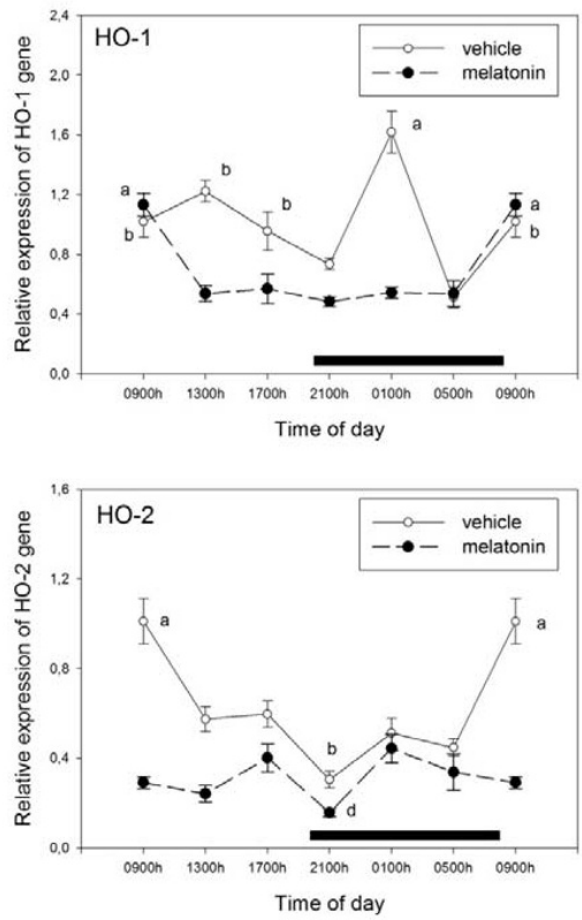

Figure 2 Effect of melatonin administration on 24-h changes in expression of mRNA for HO-1 and $\mathrm{HO}-2$ in medial basal hypothalamus (MBH) of rats. Groups of 6-8 rats were killed by decapitation at six different time intervals throughout a 24-h cycle. MBH mRNA levels encoding HO-1 and HO-2 enzymes were measured as described in the text. Shown are the mean values \pm SEM of mRNA determination as measured by triplicate real-time PCR analyses of RNA samples. Letters denote significant differences in a one-way ANOVA followed by a Bonferroni's multiple comparison test, as follows: ${ }^{a} P<0.01$ vs all other mean values; ${ }^{\mathrm{b}} P<0.01$ vs 0100 and $0500 \mathrm{~h}$; ${ }^{\mathrm{c} P}<0.01$ vs 0900 , 1300 and $1700 \mathrm{~h}, P<0.05$ vs $0100 \mathrm{~h}$; ${ }^{\mathrm{d}} P<0.01$ vs $0100 \mathrm{~h}, P<0.05$ vs $1700 \mathrm{~h}$. For further statistical analysis, see text

Figure 2 shows the results of mRNA expression of MBH HO-1 and HO-2. In controls, mRNA expression of HO-1 was higher at the middle of the scotophase $(0100 \mathrm{~h})$ whereas that of HO-2 attained its maximum at the early light phase of daily photoperiod $(0900 \mathrm{~h})$. Melatonin treatment decreased by $40 \%$ and $45 \%$ mRNA expression of HO-1 and HO-2, respectively ( $\mathrm{F}=63.3$ and 54.5; $P<0.0001$, factorial ANOVA). In every case, significant interactions 'treatment $\mathrm{x}$ time' were found, i.e. melatonin treatment shifted the maximum of HO-1 mRNA expression to the early light phase $(0900 \mathrm{~h} ; \mathrm{F}=$ $15.1 ; P<0.0001)$ or brought about a bimodal pattern of HO-2 mRNA expression (peaks at 1700 and $0100 \mathrm{~h} ; \mathrm{F}=$ 8.14; $P<0.0001$; Fig. 2).
MBH mRNA expression of $\mathrm{Cu} / \mathrm{Zn}-\mathrm{SOD}, \mathrm{Mn}-\mathrm{SOD}$ and catalase is shown in Figure 3. For the three antioxidant enzymes tested, mRNA expression in controls did not exhibit significant 24-h variations. After melatonin treatment, a bimodal pattern in SOD gene expression was found, with maxima at late afternoon $(1700 \mathrm{~h})$ and late night $(0500 \mathrm{~h}$; $\mathrm{Cu} / \mathrm{Zn}-\mathrm{SOD}, \mathrm{F}=2.74$ for the interaction 'treatment $\mathrm{x}$ time'; $P<0.03$ ) or at early and late photophase ( $0900 \mathrm{~h}$ and $1700 \mathrm{~h}$; Mn-SOD, F = 2.64; $P<$ $0.04)$, respectively. Melatonin brought about a maximum in MBH catalase expression at early photophase $(0900 \mathrm{~h}$; $\mathrm{F}=2.71$ for the interaction 'treatment $\mathrm{x}$ time'; $P<0.04$; Fig. 3, lower panel). Although after main factor analysis in the factorial ANOVA probability values for treatment did not attain significance, mRNA expression of antioxidant enzymes was significantly higher in melatoninadministered rats than in controls at certain time points, i.e. at $0500 \mathrm{~h}$ for $\mathrm{Cu} / \mathrm{Zn}-\mathrm{SOD}(P<0.01$, Student's $t$-test $)$ or at $0900 \mathrm{~h}$ for Mn-SOD and catalase $(P<0.01$ and $P<$ 0.04, Student's $t$-test; Fig. 3).

\section{Discussion}

The foregoing results underline the existence of significant 24-h changes in gene expression of the inducible isoform of the pro-oxidant enzyme NOS (NOS-2) but not of the neuronal isoform NOS-1 in $\mathrm{MBH}$ of unstressed rats. MBH mRNA for both the inducible (HO-1) and constitutive (HO-2) isoforms of HO showed a significant 24-h pattern with a maximum at the middle of the dark phase or at the early light phase, respectively. None of mRNAs encoding the antioxidant enzymes $\mathrm{Cu} / \mathrm{Zn}-\mathrm{SOD}, \mathrm{Mn}-$ SOD and catalase exhibited significant $24-\mathrm{h}$ variations in rat $\mathrm{MBH}$ under control conditions. Daily melatonin administration in the drinking water for 1 month decreased significantly mRNAs for NOS-1, NOS-2, HO-1 and HO-2 as well as changed their 24-h profile. In the case of $\mathrm{Cu} / \mathrm{Zn}-\mathrm{SOD}, \mathrm{Mn}-\mathrm{SOD}$ or catalase, a stimulation of gene expression by melatonin was seen at certain time intervals.

NOS, that catalyzes the formation of NO from Larginine, was first purified and cloned from rat brain and is located throughout the brain, among them several hypothalamic nuclei. ${ }^{21}$ The neuronal isoform of NOS (NOS-1) is constitutively expressed in neurons whereas expression of the inducible (macrophage) isoform NOS-2 occurs both in glial cells and neurons. $^{22}$ NOS has been detected in several hypothalamic areas including the suprachiasmatic, ${ }^{23}$ supra-optic, paraventricular, ventromedial and dorsomedial nuclei. ${ }^{21}$ NOS is also present in fibers at 

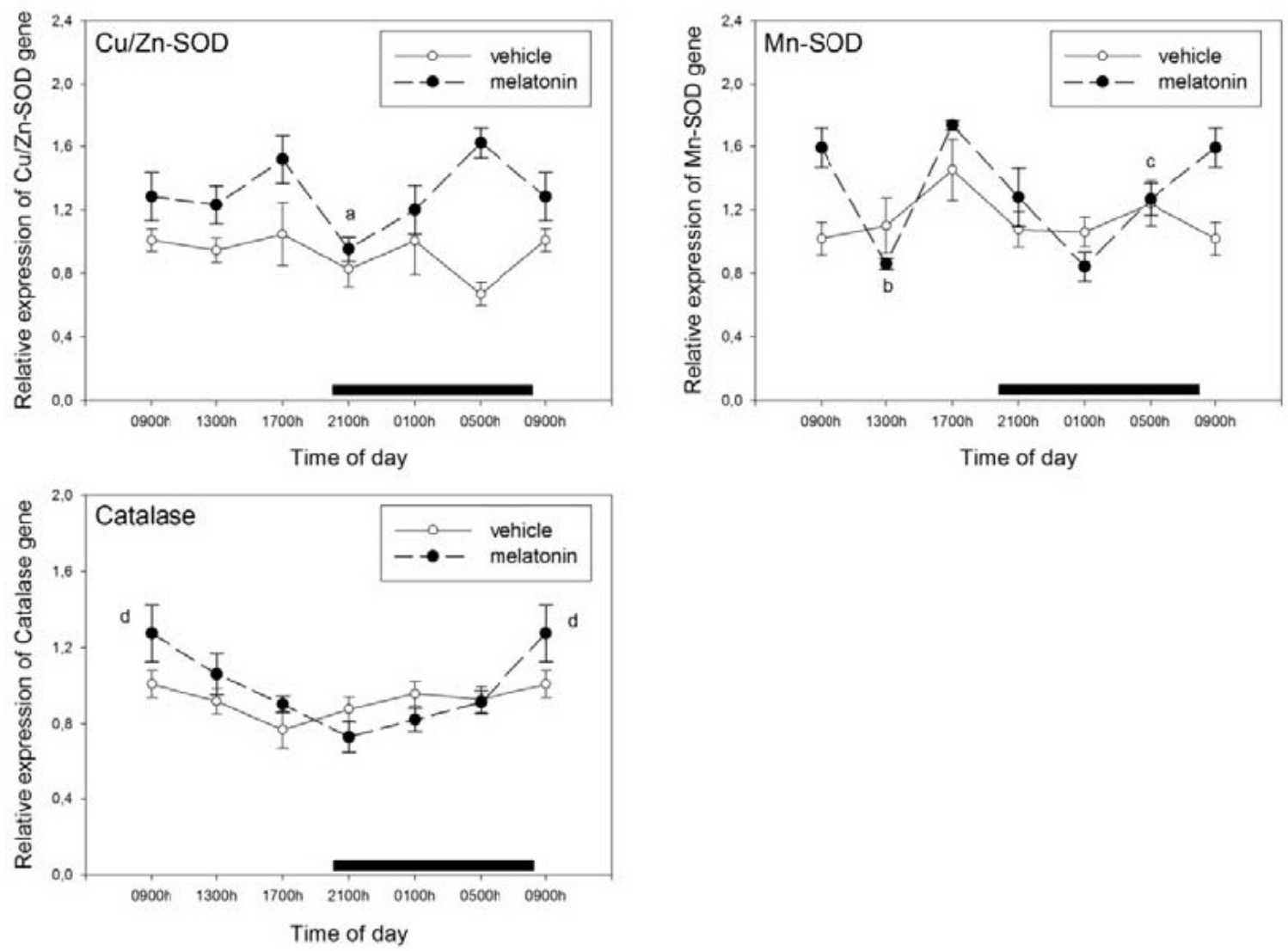

Figure 3 Effect of melatonin administration on 24-h changes in expression of mRNA for Cu/Zn-SOD, Mn-SOD and catalase in medial basal hypothalamus (MBH) of rats. Groups of 6-8 rats were killed by decapitation at six different time intervals throughout a 24-h cycle. MBH mRNA levels encoding Cu/Zn-SOD, Mn-SOD and catalase enzymes were measured as described in the text. Shown are the mean values \pm SEM of mRNA determination as measured by triplicate real-time PCR analyses of RNA samples. Letters denote significant differences in a one-way ANOVA followed by a Bonferroni's multiple comparison test, as follows: ${ }^{\mathrm{P}} \boldsymbol{P}<0.05$ vs $1700 \mathrm{~h}, P<0.01$ vs $0500 \mathrm{~h}$; ${ }^{\mathrm{b}} P<0.05$ vs $0500 \mathrm{~h}, P<0.01$ vs 0900 and $1700 \mathrm{~h} ;{ }^{\mathrm{c}} P<0.05$ vs $0100 \mathrm{~h}, P<0.01$ vs 0900,1300 and $1700 \mathrm{~h} ;{ }^{\mathrm{d}} P<0.01$ vs $2100 \mathrm{~h}, P<$ 0.05 vs 1600,0100 and $0500 \mathrm{~h}$. For further statistical analysis, see text

the median eminence, mainly in the internal layer and around blood vessels of the portal system. ${ }^{24}$ Indeed, NO may play an important role in the diurnal changes of $\mathrm{MBH}$ activity. For example, pretreatment with antisense oligodeoxynucleotide against NOS-1 mRNA, but not against that of NOS-2, was effective in preventing the diurnal changes of tuberoinfundibular dopaminergic neuronal activity and prolactin. ${ }^{25}$

The present data on the diurnal maximum in inducible NOS (NOS-2) mRNA in MBH accord with histochemical studies indicating that NOS levels in mouse intermediolateral column of the spinal cord underwent a strong circadian cycle with the highest levels observed during the light phase. ${ }^{26}$ It is interesting that the activity of brain NOS exhibits a diurnal variation peaking during the night, $180^{\circ}$ out of phase of gene expression. ${ }^{12}$ There are several possible reasons for the lack of correlation between enzyme expression and its activity, among them enzyme activity modulation by post-transcriptional modifications, such as protein-protein interactions or phosphorylation.

HO has an important role in controlling the redox state of the cell by functioning as a rate-limiting enzyme in the heme degradation process. ${ }^{1}$ The oxidative degradation of heme, which results in the formation of equimolar amounts of carbon monoxide (CO) and biliverdin, is catalyzed by the microsomal enzyme HO. Biliverdin and bilirubin are known to be potent antioxidants. ${ }^{27}$ Three isoforms of $\mathrm{HO}$ have been identified. HO-1 is an inducible isoform that is responsive to various stimuli, including oxidative stress. Overexpression of HO-1 protects neuronal and non-neuronal cells from oxidative stress. ${ }^{27} \mathrm{HO}-2$ is a constitutive isoform that is highly concentrated in the 
brain and is less inducible by oxidative stress. The remaining isoform, HO-3, has been less well characterized. ${ }^{27}$ Various hypothalamic nuclei displayed both HO-1 and HO-2 mRNA proteins ${ }^{28}$ and enzymatic activity, ${ }^{13}$ explaining the high $\mathrm{CO}$ production rate that the hypothalamus exhibits. This supports the role of $\mathrm{CO}$, endogenously formed through the action of this enzyme, in neuronal transmission, neuroendocrine regulation and other physiological functions including the circadian function. ${ }^{29}$ As most cellular pathways exhibit circadian/diurnal rhythms, it is surprising that SOD and catalase gene expression appeared as constitutive in $\mathrm{MBH}$. The heterogeneous nature of the tissue examined is a plausible explanation for the findings. It is possible that the nuclei represented in the MBH block exhibit rhythms with different phases that, on average, give the impression of a non-cyclic gene expression.

The inhibitory effect of melatonin on HO-1 and HO-2 mRNA reported in the present study is puzzling. It can be tentatively interpreted in terms of either reduction of oxidative load by melatonin (i.e. less need of HO-1 expression), and/or interference of melatonin with (circadian) signaling regulating gene expression of these enzymes. Since gene expression does not necessarily correlate with enzymatic activity, a more accurate evaluation of melatonin effect will be given by testing its role in the regulation of $\mathrm{MBH} \mathrm{HO}$ activity and protein levels.

The mechanisms involved in regulation of gene expression by melatonin may involve receptormediated and receptor-independent phenomena. Among the latter, inhibition of ROS generation is attractive. Since ROS play a role in cellular signaling processes, including transcription factors activities such NF- $\mathrm{KB}$ and AP-1, a decrease of free radicals by melatonin would allow the repression of redoxsensitive transcription factors, which could regulate gene transcription. ${ }^{30,31}$ It was suggested that melatonin-induced neuroprotective activity is mediated via the potentiation of other brain antioxidants (e.g. ascorbic acid and other, yet unidentified compounds) that, by altering the cell's redox state, attenuate the subsequent activation of $\mathrm{NF}-\mathrm{\kappa B}$ and AP-1. ${ }^{32}$ Indeed, the induction of HO-1 expression is a NO-dependent process ${ }^{33}$ and the significant inhibition of NOS-1 and NOS-2 mRNA expression given by melatonin may be instrumental in the observations hereby reported.

The detoxification of ROS in brain cells involves the co-operative action of intracellular antioxidant enzymes, among them $\mathrm{Cu} / \mathrm{Zn}$-SOD that is cytosolic, $\mathrm{Mn}-\mathrm{SOD}$ that is mitochondrial, and catalase that is present in peroxisomes. ${ }^{31}$ Although the rat brain activity of these three enzymes are augmented by melatonin, $6,7,34,35$ the present results indicate that the stimulatory effect of melatonin on mRNA synthesis of antioxidant enzymes was less pronounced than expected. As in the case of NOS, post-transcriptional modifications may explain the dissociation in effects as far as gene expression and enzyme activity.

Summarizing, an important aspect in melatonin's role in neuroprotection includes the attenuation of radical formation via anti-excitatory and antiinflammatory effects. A remarkable body of evidence indicates that melatonin exerts significant neuroprotective effects in numerous brain cell culture and in vivo systems. ${ }^{2}$ This is not restricted to scavenging but includes down-regulation of gene expression of pro-oxidant and up-regulation of gene expression of antioxidant enzymes, like those reported herein. Other antioxidant effects could be mediated by binding to quinone reductase 2 , which had previously been assumed to represent a new melatonin receptor. ${ }^{36}$ More recently, mitochondrial effects of melatonin have come into focus, including safe-guarding of respiratory electron flux, reduction of oxidant formation by lowering electron leakage) and inhibition of opening of the mitochondrial permeability transition pore. ${ }^{37}$ Since most of published studies on neuroprotective activity of melatonin were performed at single time points, generally at morning hours, and in view of the 24-h changes in redox state that occurs in a number of tissues, ${ }^{38,39}$ it should be important to include a chronopharmacological approach in the analysis of the above mentioned effects of melatonin. Further studies are needed to shed light on the mechanisms that explain melatonin activity on HO-1 and HO-2 gene expression. In particular, enzyme activity assessment and Western blotting analysis of enzyme protein levels would be helpful in this respect.

\section{Conclusions}

Chronic melatonin administration in the drinking water decreased significantly mRNAs for NOS-1, NOS-2, HO-1 and HO-2 as well as changed their 24-h profile. Melatonin augmented gene expression of the antioxidant enzymes $\mathrm{Cu} / \mathrm{Zn}$-SOD, Mn-SOD or catalase at certain time intervals only. Therefore, the present results are compatible with the view that the principal indirect (i.e. gene expression of redox pathway enzymes) effect of melatonin on redox pathway in the hypothalamus is mainly exerted via down-regulation of pro-oxidant enzyme mRNAs. 


\section{Acknowledgements}

This work was supported by grant PI 050163 from the Fondo de Investigaciones Sanitarias (FIS), Madrid Spain, and the Agencia Nacional de Promoción Cientifica y Tecnológica, Argentina (PICT 200701045). DPC is a Research Career Awarded from the Argentine Research Council (CONICET).

\section{References}

1. Mancuso C, Scapagini G, Curro D et al. Mitochondrial dysfunction, free radical generation and cellular stress response in neurodegenerative disorders. Front Biosci 2007; 12: 1107-1123.

2. Tan DX, Manchester LC, Terron MP, Flores LJ, Reiter RJ. One molecule, many derivatives: a never-ending interaction of melatonin with reactive oxygen and nitrogen species? J Pineal Res 2007; 42: 28-42.

3. Pandi-Perumal SR, Srinivasan V, Maestroni GJM, Cardinali DP, Poeggeler B, Hardeland R. Melatonin: nature's most versatile biological signal? FEBS J 2006; 273: 2813-2838.

4. Pozo D, Reiter RJ, Calvo JR, Guerrero JM. Physiological concentrations of melatonin inhibit nitric oxide synthase in rat cerebellum. Life Sci 1994; 55: L455-L460.

5. Uz T, Longone P, Manev $\mathrm{H}$. Increased hippocampal 5-lipoxygenase mRNA content in melatonin-deficient, pinealectomized rats. $J$ Neurochem 1997; 69: 2220-2223.

6. Liu F, Ng TB. Effect of pineal indoles on activities of the antioxidant defense enzymes superoxide dismutase, catalase, and glutathione reductase, and levels of reduced and oxidized glutathione in rat tissues. Biochem Cell Biol 2000; 78: 447-453.

7. Montilla P, Tunez I, Munoz MC, Soria JV, Lopez A. Antioxidative effect of melatonin in rat brain oxidative stress induced by adriamycin. Rev Esp Fisiol 1997; 53: 301-305.

8. Barlow-Walden LR, Reiter RJ, Abe $\mathrm{M}$ et al. Melatonin stimulates brain glutathione peroxidase activity. Neurochem Int 1995; 26: 497-502.

9. Pablos MI, Reiter RJ, Chuang JI et al. Acutely administered melatonin reduces oxidative damage in lung and brain induced by hyperbaric oxygen. J Appl Physiol 1997; 83: 354-358.

10. Winiarska K, Fraczyk T, Malinska D, Drozak J, Bryla J. Melatonin attenuates diabetes-induced oxidative stress in rabbits. J Pineal Res 2006; 40: $168-176$.

11. Merrow M, Roenneberg T. Circadian clocks: running on redox. Cell 2001; 106: 141-143.

12. Ayers NA, Kapas L, Krueger JM. Circadian variation of nitric oxide synthase activity and cytosolic protein levels in rat brain. Brain Res 1996; 707: 127-130.

13. Rubio MF, Agostino PV, Ferreyra GA, Golombek DA. Circadian heme oxygenase activity in the hamster suprachiasmatic nuclei. Neurosci Lett 2003; 353: 9-12

14. Martin V, Sainz RM, Mayo JC, Antolin I, Herrera F, Rodriguez C. Daily rhythm of gene expression in rat superoxide dismutases. Endocr Res 2003; 29: 83-95.

15. Sani M, Sebai H, Gadacha W, Boughattas NA, Reinberg A, Mossadok BA. Catalase activity and rhythmic patterns in mouse brain, kidney and liver. Comp Biochem Physiol B Biochem Mol Biol 2006; 145: 331-337.

16. Poliandri AH, Esquifino AI, Cano $\mathrm{P}$ et al. In vivo protective effect of melatonin on cadmium-induced changes in redox balance and gene expression in rat hypothalamus and anterior pituitary. $J$ Pineal Res 2006; 41: 238-246.

17. Cardinali DP, Garcia AP, Cano P, Esquifino AI. Melatonin role in experimental arthritis. Curr Drug Targets Immune Endocr Metab Disord 2004; 4: $1-10$

18. Szentagothai B, Flerko B, Mess B, Halász B. Hypothalamic Control of the Anterior Pituitary, 3rd edn. Budapest: Akademiai Kiado, 1968.
19. Institute of Laboratory Animal Resources CoLSNRC. Guide for the Care and Use of Laboratory Animals. Washington, DC: National Academy Press, 1996.

20. Livak KJ, Schmittgen TD. Analysis of relative gene expression data using real-time quantitative PCR and the $2^{-\Delta \Delta C t}$ method. Methods 2001; 25: 402-8.

21. Ceccatelli S. Expression and plasticity of NO synthase in the neuroendocrine system. Brain Res Bull 1997; 44: 533-538.

22. Wong ML, Rettori V, al Shekhlee A et al. Inducible nitric oxide synthase gene expression in the brain during systemic inflammation. Nat Med 1996; 2: 581-584.

23. Plano SA, Agostino PV, Golombek DA. Extracellular nitric oxide signaling in the hamster biological clock. FEBS Lett 2007; 581: 5500-5504.

24. Knauf C, Ferreira S, Hamdane $\mathrm{M}$ et al. Variation of endothelial nitric oxide synthase synthesis in the median eminence during the rat estrous cycle: an additional argument for the implication of vascular blood vessel in the control of GnRH release. Endocrinology 2001; 142: 4288-4294.

25. Yen SH, Pan JT. Nitric oxide plays an important role in the diurnal change of tuberoinfundibular dopaminergic neuronal activity and prolactin secretion in ovariectomized, estrogen/progesterone-treated rats. Endocrinology 1999; 140: 286-291.

26. Clemens S, Sawchuk MA, Hochman S. Reversal of the circadian expression of tyrosine-hydroxylase but not nitric oxide synthase levels in the spinal cord of dopamine D3 receptor knockout mice. Neuroscience 2005; 133: 353-357.

27. Pae HO, Kim EC, Chung HT. Integrative survival response evoked by heme oxygenase-1 and heme metabolites. J Clin Biochem Nutr 2008; 42 197-203.

28. Ewing JF, Maines MD. Histochemical localization of heme oxygenase2 protein and mRNA expression in rat brain. Brain Res Brain Res Protoc 1997; 1: 165-174.

29. Mancuso C, Kostoglou-Athanassiou I, Forsling ML et al. Activation of heme oxygenase and consequent carbon monoxide formation inhibits the release of arginine vasopressin from rat hypothalamic explants. Molecular linkage between heme catabolism and neuroendocrine function. Brain Res Mol Brain Res 1997; 50: 267-276.

30. Lezoualc'h F, Sparapani M, Behl C. $N$-Acetyl-serotonin (normelatonin) and melatonin protect neurons against oxidative challenges and suppress the activity of the transcription factor NF-kappaB. J Pineal Res 1998; 24: 168-178.

31. Rodriguez C, Mayo JC, Sainz RM et al. Regulation of antioxidant enzymes: a significant role for melatonin. J Pineal Res 2004; 36: 1-9.

32. Beni SM, Kohen R, Reiter RJ, Tan DX, Shohami E. Melatonin-induced neuroprotection after closed head injury is associated with increased brain antioxidants and attenuated late-phase activation of NF-kappa B and AP-1. FASEB J 2004; 18: 149-151.

33. Alba G, El Bekay R, Chacon P et al. Heme oxygenase-1 expression is down-regulated by angiotensin II and under hypertension in human neutrophils. J Leukoc Biol 2008; 84: 397-405.

34. Mayo JC, Sainz RM, Antoli I, Herrera F, Martin V, Rodriguez C. Melatonin regulation of antioxidant enzyme gene expression. Cell Mol Life Sci 2002; 59: 1706-1713.

35. Subramanian P, Mirunalini S, Pandi-Perumal SR, Trakht I, Cardinali DP. Melatonin treatment improves the antioxidant status and decreases lipid content in brain and liver of rats. Eur J Pharmacol 2007; 571: 116-119.

36. Tan DX, Manchester LC, Terron MP, Flores LJ, Tamura H, Reiter RJ Melatonin as a naturally occurring co-substrate of quinone reductase-2, the putative MT3 melatonin membrane receptor: hypothesis and significance. J Pineal Res 2007; 43: 317-320.

37. Acuna-Castroviejo D, Escames G, Rodriguez MI, Lopez LC. Melatonin role in the mitochondrial function. Front Biosci 2007; 12: 947-963.

38. Hardeland R, Coto-Montes A, Poeggeler B. Circadian rhythms, oxidative stress, and antioxidative defense mechanisms. Chronobiol Int 2003; 20: 921-962.

39. Subramanian P, Dakshayani K, Pandi-Perumal SR, Trakht I, Cardinali DP. 24-Hour rhythms in oxidative stress during hepatocarcinogenesis in rats: effect of melatonin or $\alpha$-ketoglutarate. Redox Report 2008; 13: $78-86$. 


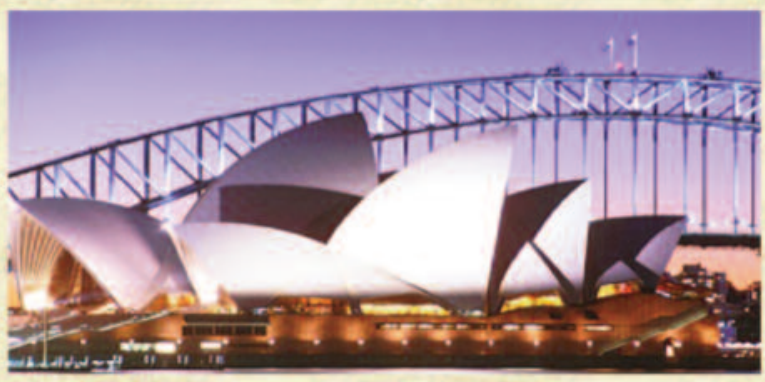

\title{
Redox Processes in Chemistry, Biology and Medicine
}

\author{
1-4 December 2009 \\ University of Sydney \\ Veterinary Conference Centre
}

http://www.pathology.usyd.edu.au/sfrra2009.htm

Email Prof Roland Stocker rstocker@med.usyd.edu.au

The 5th Joint Meeting of the Societies for Free Radical Research Australasia and Japan and the $11^{\text {th }}$ Annual Meeting of the Mutagenesis and Experimental Pathology Society of Australasia

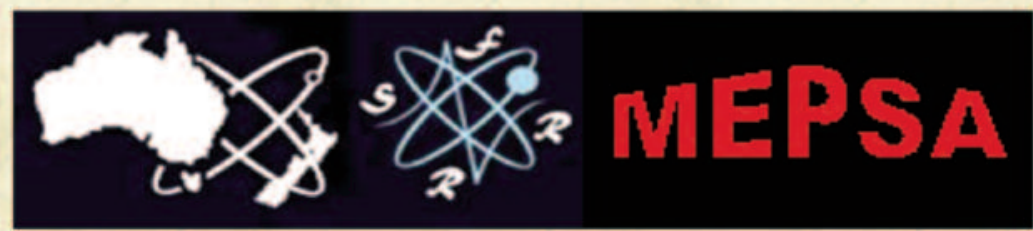

